\title{
UTJECAJ USKLAĐIVANJA PRIVATNOG I PROFESIONALNOG ŽIVOTA NA MENTALNO ZDRAVLJE ŽENA RADNICA U VEZI S OSTVARIVANJEM PRAVA NA RODILJNI DOPUST
}

UDK 613.86:369.221.6](497.6)

PRIMLJENO: 1.10 .2020$.

PRIHVAĆENO: 15.3 .2021

Ovo djelo je dano na korištenje pod Creative Commons Attribution 4.0 International License

SAŽETAK: Usklađivanje privatnog života koji uključuje prije svega majčinstvo, brigu o djeci, kući i brojne druge obveze, i profesionalnog života koji obuhvaća obrazovanje, zapošljavanje, usavršavanje i posvećenost poslu, predstavlja iznimno složen problem s kojim se susreću žene na području rada i radnih odnosa. U današnje vrijeme žene su postale dvostruko ili višestruko opterećene. Pred njih se stavlja svojevrstan izbor između privatnog i profesionalnog života te ih se izlaže životnim izborima i izazovima koji nisu svojstveni muškarcima. Stoga žene radnice sve češće koriste minimum rodiljnog dopusta, a brigu o djeci, obitelji i domu prepuštaju drugim osobama ili ustanovama samo kako bi zadržale posao i postigle profesionalno usavršavanje i napredovanje. Zbog konstantne izloženosti pritiscima i očekivanjima kako na planu privatnog, tako i na planu profesionalnog života istovremeno, kod žena radnica mogu se razviti određeni poremećaji i stanja koja u značajnoj mjeri mogu utjecati na njihovo mentalno zdravlje. Važeći propisi u Bosni i Hercegovini pružaju minimum prava, ali nedovoljno za uspostavljanje adekvatnog balansa između privatnog i profesionalnog života žena radnica.

Ključne riječi: privatni život, profesionalni život, žene radnice, mentalno zdravlje, rodiljni dopust, zakonodavstvo u Bosni i Hercegovini

\section{UVOD}

Nakon industrijske revolucije, a posebno zbog emancipacije i seksualne revolucije posljednjih desetljeća, ženama je olakšan pristup obrazovanju, zapošljavanju i radu, ali su im istovremeno ostale sve obveze iz privatnog života koje su do tada imale. Ženama se, ustvari, poslu u kući pridodao onaj na radnom mjestu. To je dovelo do pojave sve većeg broja žena koje su zbog uspjeha u poslovnom svijetu, isključivo ili najvećim dijelom usmjerene na razvoj karijere, a obiteljski život stavljaju u drugi plan. U prilog ovoj konstata-

*Dr. sc. Jasmina Bešlagić (jasmina.beslagic@unbi.ba), Pravn fakultet Univerziteta u Bihaću, Mehe Hadžiabdića bb, 77000 Bihać, $\mathrm{BiH}$, dr. sc. Azra Bakrač (azra.bakrac@unbi.ba), Biotehnički fakultet Univerziteta u Bihaću, Luke Marjanovića bb, 77000 Bihać, BiH, dr. sc. Atif Hodžić (atif.hodzic@unbi.ba),dr. sc. Esad Bajramović (esad bajramovic@unbi.ba), Tehnički fakultet Univerziteta u Bihaću, Ulica Dr. Irfana Ljubijankića bb, 77000 Bihać, BiH. ciji govore i provedena istraživanja koja pokazuju kako žene, posebno one zaposlene u privatnim poduzećima na stručnim poslovima, sve češće koriste minimum dana rodiljnog dopusta, samo kako bi zadržale posao i postigle profesionalno usavršavanje i napredovanje. ${ }^{1}$ Jedan od osnovnih uzroka takvom stanju jest činjenica da je organizacija rada u većini zemalja podređena muškarcu i njegovim osobinama, dok se posebnosti i osobine žene radnice zanemaruju. ${ }^{2}$ Jednako takva je i uloga institucija koje se bave organiziranom bri-

'Borić, R., Šinko, M., Prlenda, S.: Ostvarivanje politike jednakih mogućnosti za tekstilne radnice/ke, Centar za ženske studije, Zagreb, 2009., str. 36-37. Novija istraživanja govore o potrebi i politikama uključivanja očeva u skrb o djeci u njihovoj najranijoj životnoj dobi, te učincima dopusta namjenjenih skrbi za djecu sa statističkim podacima, vidi više u: Dobrotić, l.: Politike usklađivanja obiteljskih obaveza i plaćenog rada i položaj roditelja na tržištu rada, Revija za socijalnu politiku, 22, 2015., 3, 353-374, str. 359-366.

${ }^{2}$ Volarević, M.: Novi feminizam i kulturalna promocija žene majke-radnice, Obnovljeni život, 67, 2012., 2, 223-237, str. 224. 
gom za djecu i starije osobe, a koja bi trebala biti organizirana na takav način da omogućava prilagođavanje individualnim potrebama konkretne obitelji i što lakše usklađivanje njihovih radnih i obiteljskih obveza. ${ }^{3}$

Stoga se može reći kako takav tretman žena radnica predstavlja jedan od oblika diskriminacije na osnovi spola u pogledu ostvarivanja osnovnih ljudskih, a posebno prava iz radnog odnosa i drugih srodnih prava. S druge strane, takvo postupanje prema ženama je dobrim dijelom razlogom sve manjeg nataliteta u brojnim suvremenim društvima.

\section{USKLAĐIVANJE PRIVATNOG I PROFESIONALNOG ŽIVOTA ŽENA RADNICA}

Uzimajući u obzir dvostruku, a često i višestruku opterećenost žena radnica u pogledu ostvarivanja ravnoteže između privatnog života koji uključuje majčinstvo, brigu o djeci, kući i brojne druge obveze; i profesionalnog života koji obuhvaća obrazovanje, zapošljavanje, usavršavanje i posvećenost poslu, može se sa sigurnošću reći kako se radi o vrlo složenom problemu s kojim se susreću žene na području rada i radnih odnosa. Pred žene radnice stavlja se izbor između dva gotovo podjednako važna područja njihovih života, a koji im ne ostavlja suviše prostora za prosuđivanje, jer se radi o životnim kategorijama koje su apsolutno neusporedive.

Kada se razmatra naznačeni problem, postavlja se pitanje zašto se uopće pred žene postavljaju takve vrste izbora? Naime, žene danas uistinu sve više rade na svojim radnim mjestima, dok se njihov radni doprinos u kući gotovo uopće nije promijenio. Zahtjevi rada nisu usklađeni s obiteljskim potrebama pa se, u pravilu, poslu u kući pridodao onaj na radnom mjestu, a sve to opet zbog poboljšavanja kućnog budžeta, ${ }^{4}$ implementacije principa ravnopravnosti u društvene tokove, te uopće suvremenih trendova emancipacije žena.

\footnotetext{
${ }^{3}$ Rebac, I.: Izravni i neizravni oblici diskriminacije na tržištu rada, zaštita od diskriminacije u kolektivnim ugovorima u Republic Hrvatskoj, Radno pravo, 7-8, 2006., 6-28, str. 8.

${ }^{4}$ Galić, B.: Žene i rad u suvremenom društvu - značaj „orodnjenog“ rada. Sociologija i prostor, 49, 2011., 1, 25-48, str. 43.
}

Ovom prilikom trebalo bi napomenuti kako pronatalitetna i antidiskriminacijska zakonodavstva demokratski uređenih društava jamče ravnopravnost roditelja i staratelja u usklađivanju obveza iz obiteljskog i profesionalnog života. ${ }^{5}$

Upravo zbog još uvijek tradicionalnog shvaćanja uloge žene u društvu, smatra se da je ženi imanentnija uloga majke i kućanice, pa se zato pretpostavlja da joj je karijera na drugom mjestu, što poslodavcima obično stvara problem prilikom donošenja odluke o zapošljavanju ili napredovanju radnika ženskog spola. ${ }^{6}$ Zbog nedovoljne podrške društvene zajednice, ženama se šalje jasna poruka: mjesto žene u obitelji je uz djecu, pri čemu se ne vodi računa o posljedicama koje ova socijalna norma proizvodi. ${ }^{7}$

Međutim, sve je više onih žena na tržištu rada koje su profesionalno usmjerene na razvoj karijere, tako da se one isključivo bave poslom, a područje obitelji stavljaju u drugi plan. ${ }^{8}$ Unatoč tome, ipak su smještene na nižim pozicijama u rukovodećim strukturama rada i upravljanja te su izložene nejednakosti plaća u odnosu na muškarce. ${ }^{9}$

Usklađivanje obiteljske i profesionalne uloge žena u društvu još nigdje nije postignuto na zadovoljavajući način, iako postoje zemlje koje ovom području pridaju posebnu važnost i pokušavaju djelovati putem svojih rodnih politika na usklađivanje i ravnomjerno opterećenje žena i muškaraca u usklađivanju njihovim obiteljskih i radnih uloga. ${ }^{10} \mathrm{U}$ Bosni i Hercegovini to, nažalost, nije slučaj. Naime, Bosna i Hercegovina je postsocijalistička država koja se veoma teško oslobađa relikata prošlosti. Tako je i dalje aktualan tzv. model dvije plaće (two wages model) koji podrazumijeva zapošljavanje žena, ali ne zbog bilo kakvog senzibiliteta prema ženama, već iz potreba

'Član 13., stav 1., tačka f., Zakon o ravnopravnosti spolova Bosne i Hercegovine, Službeni glasnik Bosne i Hercegovine, broj 32/10. prečišćeni tekst.

${ }^{6}$ Jergovski, A.: Stakleni strop, Granice u napredovanju žena na radnom mjestu. Obnovljeni život, 65, 2010., 3, 403-412, str. 406.

${ }^{7}$ Borić, R., Šinko, M., Prlenda, S.: Ostvarivanje politike jednakih mogućnosti za tekstilne radnice/ke, Centar za ženske studije, Zagreb, 2009., str. 36 .

${ }^{8}$ Galić, B.: Žene i rad u suvremenom društvu - značaj „orodnjenog" rada. Sociologija i prostor, 49, 2011., 1, 25-48, str. 43.

${ }^{9}$ Galić, B.: Žene i rad u suvremenom društvu - značaj „orodnjenog" rada. Sociologija i prostor, 49, 2011., 1, 25-48, str. 29.

${ }^{10}$ Galić, B.: Žene i rad u suvremenom društvu - značaj "orodnjenog" rada. Sociologija i prostor, 49, 2011., 1, 25-48, str. 44. 
za izlaženjem države iz krize koja ju je zahvatila nakon II. svjetskog rata, ${ }^{11}$ odnosno nakon agresije na Bosnu i Hercegovinu, ako se promatra novije razdoblje. ${ }^{12}$ Tako su žene postale višestruko opterećene brigom za djecu, muškarcima i starima, brigom oko kućanstva, samim poslom, ali i političkim angažmanom. Nije zanemariva niti činjenica da je posljednjim izmjenama socijalnog zakonodavstva u Federaciji Bosne i Hercegovine izjednačena starosna dob muškarca i žene, kao jedan od uvjeta za stjecanje prava na starosnu mirovinu, ${ }^{13}$ osim kada je u pitanju stjecanje prava na prijevremenu starosnu mirovinu. ${ }^{14}$ Navedeno unatoč činjenici da je praksa Europskog suda za ljudska prava usmjerena ka tome da ostavlja mogućnost da nacionalnim zakonodavstvom ovo područje može biti i drugačije regulirano s obzirom na poimanje uloge žene u konkretnom društvenom sustavu, čime bi ženama radnicama u velikoj mjeri bilo olakšano uspostavljanje ravnoteže između obiteljskih i profesionalnih obveza. Tako su se u predmetu Stec i drugi v Ujedinjenog Kraljevstva podnositelji žalili da su, s obzirom na različito doba umirovljenja za muškarce i žene, bili oštećeni izmjenom olakšica koja je određena prema dobi umirovljenja. Europski sud za ljudska prava utvrdio je da se spolna diskriminacija u načelu može opravdati samo onda kada za to postoje „iznimno jaki razlozi". Međutim, prema stavu Europskog suda za ljudska prava, „državi se obično dopušta široka sloboda procjene kada se radi o opštim mjerama privredne ili socijalne strategije... Zbog njihovog direktnog poznavanja vlasti-

\footnotetext{
${ }^{11}$ Bašić, A.: Rodne uloge i stereotipi, Helsinški parlament građana, Banja Luka, 2007., str. 7.

${ }^{12}$ Prema nekim autorima, danas postoje tri modela uzdržavanja obitelji: 1. model muškoga hranitelja obitelji u kojem muškarac donosi ekonomsku zaradu obitelji, dok se žena brine za kućanstvo 2. modernizirani model muškoga hranitelja u kojem je muškarac i dalje glavni hranitelj, ali žena bilo povremenim poslom bilo poslom sa skraćenim radnim vremenom pridonosi kućanstvu, odnosno postaje sekundarni hranitelj; 3. dvohraniteljski model u kojem oba partnera podjednako ekonomski pridonose kućanstvu. (Akrap A., Čipin I.: Usklađivanje poslovnog i obiteljskog života u Hrvatskoj: utjecaj na fertilitet, Društvena istraživanja, 2011., 20, 1, 47-68, str. 48-49, u: Volarević, M.: Novi feminizam i kulturalna promocija žene majkeradnice, Obnovljeni život, 67, 2012., 2, 223-237, str. 224).

${ }^{13}$ Član 40., Zakon o penzijskom i invalidskom osiguranju Federacije Bosne i Hercegovine (Službene novine Federacije Bosne i Hercegovine, broj 13/18. i član 42.), Zakon o penzijskom i invalidskom osiguranju Republike Srpske (Službeni glasnik Republike Srpske, broj 134/11., 82/13., 96/13. - odluka US i 103/15.).

${ }^{14}$ Član 142. i 143., Zakon o penzijskom i invalidskom osiguranju Federacije Bosne i Hercegovine i član 42., Zakon o penzijskom i invalidskom osiguranju Republike Srpske.
}

tog društva i društvenih potreba, domaće su vlasti u principu pozvanije od međunarodnog suda ocijeniti što je po socijalnom ili gospodarskom osnovu u javnom interesu, a Europski sud za ljudska prava će uglavnom poštovati izbor zakonodavne politike, osim ako nije... očito neutemeljen". Sud je utvrdio da je po svom porijeklu različita dob za umirovljenje zapravo oblik "posebnih mjera" donesenih u svrhu ublažavanja financijskih poteškoća koje bi mogle zadesiti žene s obzirom na njihovu tradicionalnu ulogu u kući zbog koje nisu ekonomski nezavisne. Ustanovljeno je da su vlasti počele postupno uvoditi korekcije za izjednačavanje dobi umirovljenja muškaraca i žena te da nisu prešle granicu svoje slobode procjene, bilo u odluci da taj cilj postignu tijekom nekoliko godina, bilo u neuspjehu da promjene provedu ranije. $^{15}$

\section{Rodiljni dopust - zaštita žene i materinstva}

Posebno značajnu ulogu u usklađivanju privatnog i profesionalnog života ima radno-pravni institut rodiljnog dopusta. Institut rodiljnog dopusta i njegov normativni tretman je u direktnoj vezi s pronatalitetnom politikom konkretnog društva, a s obzirom na specifičan položaj žena unutar njega, od posebnog značaja za ostvarivanje antidiskriminacijske politike. S obzirom na prirodu instituta rodiljnog dopusta, te njegovo utjelovljenje putem pozitivnih propisa, njime se upravo omogućuje ženi majci radnici ostvarivanje ravnoteže između obiteljskih i poslovnih obveza.

Naime, rodiljni dopust predstavlja pravo na odsutnost s rada majke za vrijeme trajanja trudnoće, porođaja i njege djeteta. Rodiljni dopust traje kontinuirano, a duljina trajanja razlikuje se od države do države, ali s tendencijom stalnog rasta.

Pravo na rodiljni dopust je pravo proklamirano normama i standardima međunarodnog karaktera, gdje posebnu ulogu imaju konvencije Međunarodne organizacije rada koje su u primjeni u Bosni i Hercegovini, i to: Konvencija broj 3 o radu žena prije i poslije porođaja iz 1919. godine koja je revidirana 1952. i 2000. godine, Konvencija broj 111 o diskriminaciji u pogledu zapošljavanja i zanimanja iz 1958. godine te Konvencija broj

${ }^{15}$ Stec i drugi v UK, ESLJP, 65731/01 i 65900/01. 
156 o jednakim mogućnostima i jednakom tretmanu radnika i radnica: radnici s obiteljskim obvezama iz 1981. godine. ${ }^{16}$ Navedene konvencije Međunarodne organizacije rada su ratifikacijom postale dio pravnog sustava Bosne i Hercegovine te imaju primat u primjeni u odnosu na domaće pravne propise, a njima su uspostavljeni osnovni standardi u zaštiti žena radnica, trudnica i majki rodilja.

Zakonodavstvo Europske unije također značajnu pozornost posvećuje pitanju reguliranja rodiljnog dopusta i drugim pitanjima s njim u vezi, a posebno onima koja se tiču prava trudnica u radnom odnosu, kao i pravima majki porodilja nakon povratka na posao. Pored dokumenata o ljudskim pravima, konvencijskog i nekonvencijskog karaktera, posebnu ulogu ima Europska konvencija o ljudskim pravima i osnovnim slobodama iz 1950. godine Vijeća Europe, kao i osnivački i reformski ugovori Europske unije, a naročito Amsterdamski ugovor. Amsterdamskim ugovorom iz 1999. godine odredbe koje se odnose na spolnu diskriminaciju postale su sastavni dio osnivačkih ugovora Europske unije tj. Ugovora o Europskoj zajednici i Ugovora o Europskoj uniji. ${ }^{17}$ Također i Povelja o osnovnim pravima Europske unije iz 2000. godine i drugi dokumenti kojima se jamče ljudska prava građanima Europske unije, kao i brojne direktive Europske unije su značajni izvori prava iz područja zaštite žena radnica i majki u radnom odnosu. Neke od najznačajnijih direktiva koje reguliraju ovaj segment radnih odnosa su: Direktiva 92/85/EEZ o uvođenju mjera za poticanje poboljšanja zdravlja i sigurnosti na poslu trudnica i radnica koje su nedavno rodile ili doje na radnom mjestu iz 1992. godine, Direktiva 2002/73/ EZ o primjeni načela ravnopravnosti muškaraca i žena s obzirom na mogućnost zapošljavanja, stručnog osposobljavanja i napredovanja te radne uvjete iz 2002. godine, Direktiva 2006/54/ EZ o provođenju načela jednakih mogućnosti i jednakog postupanja prema muškarcima i ženama u pitanjima zapošljavanja i rada iz 2006. go-

\footnotetext{
${ }^{16}$ Puni tekstovi Konvencija dostupni u: Učur M.Đ., Laleta, S.: Konvencije Međunarodne organizacije rada s komentarima, TIM press, Pravni fakultet Sveučilišta u Rijeci, Zagreb, 2007.

${ }^{17}$ Galić, V.: Zaštita majčinstva u Europskoj uniji i hrvatski zakonodavni okvir, Pravni vjesnik: Časopis za pravne $i$ društvene znanosti Pravnog fakulteta Sveučilišta J.J. Strossmayera u Osijeku, 30, 2014., 2, 435-447, str. 436.
}

dine (preinačena verzija), Direktiva 2010/18/EU o provođenju revidiranog Okvirnog sporazuma o roditeljskom dopustu iz 2010. godine i druge. Upravo je Klauzulom 2. Okvirnog (revidiranog) sporazuma o roditeljskom dopustu uz Direktivu iz 2010. godine produljeno trajanje rodiljnog dopusta na minimalno četiri neprenosiva mjeseca. Direktivama, kao sekundarnim izvorima prava Europske unije, Unija propisuje minimum prava koje države moraju osigurati titularima, ali ostavlja prostor državama članicama da odaberu način implementacije definiranih standarda, prilagođen specifičnostima pojedinih pravnih sustava.

Prema Zakonu o radu Federacije Bosne i Hercegovine, žena za vrijeme trajanje trudnoće, porođaja i njege djeteta ima pravo na rodiljni dopust $\mathrm{u}$ trajanju od jedne godine neprekidno. ${ }^{18}$ Spomenute konvencije Međunarodne organizacije rada trajanje rodiljnog dopusta ograničavaju na najmanje 12 tjedana, uz obvezu da se jedan dio vremena nakon porođaja obvezno provede u odsutnosti s rada. Rodiljni dopust može započeti 28 dana prije očekivanog datuma porođaja na osnovi nalaza ovlaštenog liječnika. Može trajati i kraće, ali ne kraće od 42 dana nakon porođaja. ${ }^{19}$ Vrijeme trajanja rodiljnog dopusta uračunava se u staž osiguranja, a radniku pripada naknada plaće za vrijeme njegovog trajanja. ${ }^{20}$ Pitanje naknade plaće za vrijeme trajanja rodiljnog dopusta, kao i druga pitanja socijalnopravnog karaktera utvrđuju se posebnim propisima na entitetskim i kantonalnim razinama koji tretiraju područje socijalne zaštite i zaštite obitelji s djecom.

Kada govori o institutu rodiljnog dopusta, kao i pravima u vezi s njim, zakonodavac koristi izraz „radnik" jer su odredbe o rodiljnom dopustu neutralne prirode te pravo na rodiljni dopust pripada i

\footnotetext{
${ }^{18}$ Član 62., stav. 1., Zakon o radu Federacije Bosne i Hercegovine (Službene novine Federacije Bosne i Hercegovine, broj 26/16. i 89/18.), član 107., stav 1., Zakon o radu Republike Srpske (Službeni glasnik Republike Srpske, broj 1/16. i 66/18.), član 79., stav 1., Zakon o radu Brčko Distrikta Bosne i Hercegovine (Službeni glasnik Brčko Distrikta Bosne i Hercegovine, broj 34/19.).

${ }^{19}$ Član 62., stav 2. i 3., Zakon o radu Federacije Bosne i Hercegovine (član. 79., stav 3., Zakon o radu Brčko Distrikta Bosne i Hercegovine). Prema Zakonu o radu Republike Srpske, rodilja mora iskoristiti minimalno 60 dana do dobrovoljnog povratka na rad nakon porođaja (član 107., stav 3. u vezi sa članom 108., stav 1., Zakon o radu Republike Srpske).

${ }^{20}$ Član 68., stav 1., Zakon o radu Federacije Bosne i Hercegovine (član 112., stav 1., Zakon o radu Republike Srpske i član 82., stav 1. Zakon o radu Brčko Distrikta Bosne i Hercegovine).
} 
muškarcu u onom obimu koliko on nije povezan s biološki ograničavajućim čimbenicima (razdoblje trudnoće majke, sam čin porođaja i sl.). Naime, u slučaju smrti majke, napuštanja djeteta ili ako je iz opravdanih razloga majka spriječena da koristi rodiljni dopust, to pravo može koristiti i otac djeteta. ${ }^{21}$

\section{Druga prava žena radnica}

Pored navedenih odredaba koje prate pronatalitetnu politiku u Bosni i Hercegovini, tj. u njezinim administrativno-teritorijalnim jedinicama, postoje i druge odredbe u sklopu radnog zakonodavstva koje idu u prilog lakšem usklađivanju obiteljskog i profesionalnog života, posebno kada su u pitanju radnice ženskog spola. Tako je posebno zabranjeno diskriminirajuće postupanje prema trudnicama, pri čemu se poslodavcu eksplicitno zabranjuje da odbije zaposliti ženu zbog trudnoće, otkazati joj ugovor o radu iz istog razloga ili je, primjera radi, rasporediti na druge poslove ako to nije opravdano njezinim zdravstvenim stanjem i interesom. Za vrijeme trudnoće, odnosno dojenja djeteta, a uz vlastiti pismeni pristanak, žena može biti privremeno raspoređena na druge poslove samo ako to zahtijeva njezino zdravstveno stanje utvrđeno od strane ovlaštenog liječnika, ali takvo raspoređivanje ne može za posljedicu imati smanjene plaće. Ako poslodavac nije u mogućnosti da ženi osigura adekvatno raspoređivanje, u tom slučaju ona ima pravo na odsutnost s posla uz naknadu plaće. ${ }^{22}$ Nadalje, nakon isteka rodiljnog dopusta, a do djetetove navršene najmanje jedne godine života, žena ima pravo raditi polovinu punog radnog vremena, a u slučaju rođenja blizanaca i za svako naredno dijete ima pravo raditi polovinu punog radnog vremena do djetetove navršene dvije godine života. Pravo na polovinu punog radnog vremena je također neutralna zakonska odredba, pa ono pripada i ocu djeteta pod jednakim uvjetima kao i majci ako majka za to vrijeme radi puno radno vrijeme. Ako je djetetu starijem od jedne godine, prema ocjeni nadležne zdravstvene ustanove, potrebna pojačana briga

\footnotetext{
${ }^{21}$ Član 62., stav 4. i 5., Zakon o radu Federacije Bosne i Hercegovine (član 109., Zakon o radu Republike Srpske i član 79. i stav 5., Zakon o radu Brčko Distrikta Bosne i Hercegovine).

${ }^{22}$ Član 60., stav 1. i u vezi sa članom 61., Zakon o radu Federacije Bosne i Hercegovine (član 106., Zakon o radu Republike Srpske i član 78., Zakon o radu Brčko Distrikta Bosne i Hercegovine).
}

i njega, roditelji djeteta imaju pravo na polovinu punog radnog vremena do navršene tri godine života djeteta. ${ }^{23}$ Kada je u pitanju ovo pravo, neophodno je istaknuti kako roditelj za vrijeme korištenja ovog prava ima pravo na naknadu plaće za vrijeme rada s polovinom radnog vremena koju provede izvan procesa rada. ${ }^{24} \mathrm{U}$ kontekstu prava na naknadu plaće, rad s polovinom radnog vremena u svrhu pojačane brige i njege za dijete mogao bi se izjednačiti s radom sa skraćenim radnim vremenom. Žena koja nakon rodiljnog dopusta radi puno radno vrijeme također ima pravo na odsutnost s rada dva puta dnevno u trajanju od po sat vremena za dojenje djeteta, a na osnovi nalaza ovlaštenog liječnika. Ovo pravo pripada ženi do navršene jedne godine života djeteta, a vrijeme trajanja odsutnosti računa se kao puno radno vrijeme. ${ }^{25}$

Iz iznesenog evidentno je kako odredbe zakona kojima se štiti žena i materinstvo u najvećoj mjeri su spolno neutralne prirode te ostavljaju mogućnost i muškarcu, ocu djeteta, da koristi ova prava u onom obimu koliko to nije povezano isključivo s njegovom biološkom (ne)mogućnosti njihovog ostvarivanja. U tom slučaju opravdano se postavlja pitanje zašto se nomotehnički i institucionalno zakonodavac nije poslužio formulacijom "roditeljska odsutnost" (engl. parental leave, njem. elternzeit, fran. conge parentah), čime bi izbjegao situaciju da se prava kojima se reguliraju pitanja "rodiljnog dopusta" implicitno dovode u vezu samo s jednim spolom (ženom), zbog njezinog biološkog stanja trudnoće i porođaja. Ipak, u praksi je evidentno da najveći dio prava koji se tiče rodiljnog dopusta ipak koriste žene, pa se otvara pitanje stvarne ravnomjerne distribucije obiteljskih i profesionalnih obveza između žene i muškarca. U određenom obimu ovaj problem je na razini Europske unije riješen donošenjem Direktive Vijeća 2010/18/EU od 8. ožujka 2010. godine o provedbi revidiranog Okvirnog sporazuma o roditeljskom dopustu koji su sklo-

\footnotetext{
${ }^{23}$ Član 63. i 64., Zakon o radu Federacije Bosne i Hercegovine (član 110. i 111., Zakon o radu Republike Srpske i član 81. i član 82. i 83., Zakon o radu Brčko Distrikta Bosne i Hercegovine).

${ }^{24}$ Član 68., stav 3., Zakon o radu Federacije Bosne i Hercegovine (član 111., stav 3., Zakon o radu Republike Srpske i član 83., stav 5., Zakon o radu Brčko Distrikta Bosne i Hercegovine).

${ }^{25}$ Član 65., Zakon o radu Federacije Bosne i Hercegovine (član 108., stav 2., Zakon o radu Republike Srpske i član 80., stav 1., Zakon o radu Brčko Distrikta Bosne i Hercegovine).
} 
pili BUSINESSEUROPE, UEAPME, CEEP i ETUC, te o stavljanju izvan snage Direktive 96/34/EZ. ${ }^{26}$ Međutim, u ovom kontekstu posebno je značajna praksa Europskog suda pravde koji je, uzimajući u obzir činjenicu da roditeljski dopust najčešće koriste žene, ustanovio kako izbjegavanje plaćanja božićnice radnicima koji ga koriste predstavlja indirektnu diskriminaciju prema ženama te ukazuje na problem ravnomjerne distribucije obiteljskih i profesionalnih obveza i diskriminacije na osnovi spola u ostvarivanju prava u vezi s radom i radnim odnosom. ${ }^{27}$

A propos navedenih zakonskih odredaba kojima se štiti žena i majčinstvo neophodno je napomenuti kako relevantne europske institucije ukazuju na to kako i pretjerana zaštita žena može dovesti do njihove diskriminacije. ${ }^{28}$ Tako upravo odredbe o zaštiti žene i materinstva, iako ih prividno štite od diskriminacije, ponekad mogu prouzročiti diskriminaciju trudnih žena. Naime, u predmetu Mahlburg $v$ Land Mecklenburg-Vorpommern iz 2000. godine, Sud Europske zajednice utvrdio je kako odbijanje zapošljavanja trudnice na neodređeno vrijeme na radno mjesto na kojem je izložena štetnim utjecajima, tj. opasnim tvarima, predstavlja diskriminaciju na osnovi spola. S obzirom da je trudnoća privremeno stanje u kojem se nalazi žena radnica, zaključivanje ugovora o radu na neodređeno vrijeme ne predstavlja opravdani izuzetak od pravila o zabrani diskriminacije. $S$ druge strane, iako to Sud izričito ne navodi, zaključivanje ugovora na određeno vrijeme na istom radnom mjestu predstavljalo bi opravdani izuzetak, jer se radi o potrebi poslodavca za radnikom koja je temporalne naravi. ${ }^{29}$ Ovaj predmet govori u prilog tezi da bi u pogledu primjene propisa o zaštiti žene i materinstva poslodavci trebali biti iznimno oprezni kako naizgled

${ }^{26}$ Direktiva Vijeća 2010/18/EU od 8. ožujka 2010. godine o provedbi revidiranog Okvirnog sporazuma o roditeljskom dopustu, 32010L0018, OJ, L 68.

${ }^{27}$ Susanne Lewen v Lothar Denda, ESP, C-333/97, u: Vinković, M:, Zaštita majčinstva - stanje i perspektive hrvatskog radnog zakonodavstva, Radno pravo, 3, 2006., 1. 6-12, str. 12.

${ }^{28}$ Izvještaj Europske komisije o napretku za Republiku Hrvatsku iz 2005. godine, dostupno na: https://ec.europa.eu/ neighbourhoodenlargement/sites/near/files/archives/pdf/key_ documents/2005/package/sec_1424_final_progress_report_hr_en.pdf, pristupljeno: 5.9.2019.

${ }^{29}$ Mahlburg v. Land Mecklenburg-Vorpommern, ESP, C-207/98. nediskriminirajuća odredba zapravo ne bi dovela do stvarne, najčešće indirektne diskriminacije na osnovi spola. ${ }^{30}$

\section{MENTALNO ZDRAVLJE NA RADNOM MJESTU}

Svjetska zdravstvena organizacija ponudila je opću definiciju mentalnog zdravlja prema kojoj ono predstavlja "stanje dobrobiti u kojem pojedinac ostvaruje svoj potencijal, može se suočavati s uobičajenim životnim stresom, može raditi produktivno i ostvarivati rezultate te pridonijeti svojoj zajednici." ${ }^{31}$

Na mentalno zdravlje čovjeka djeluju različiti čimbenici, od društvenih promjena i okolnosti do osobnih događaja u obitelji ili okruženju. Budući da radnik najveći dio radno aktivnog dijela života provede na radnom mjestu, sve veća važnost pridaje se i utjecaju posla, odnosno stresa na poslu ili s njim u vezi na mentalno zdravlje čovjeka. Radno okruženje, karakteristike i čimbenici radnog mjesta nedvojbeno utječu na mentalno zdravlje svake zaposlene osobe. ${ }^{32}$

\section{Čimbenici rizika i posljedice za mentalno zdravlje radnika}

U današnje vrijeme na radnom mjestu postoji veliki broj rizičnih čimbenika koji mogu utjecati na mentalno zdravlje radnika: ekonomska recesija, sve veća konkurencija, produljenje radnog vremena i radnog vijeka, sve veća očekivanja poslodavaca i sl. ${ }^{33}$ Stres je gotovo neizbježno prisu-

\footnotetext{
${ }^{30} \mathrm{O}$ indirektnoj diskriminaciji vidjeti više u: Bešlagić, J.: Zabrana diskriminacije pri zapošljavanju i na radu-evropski i nacionalni aspekt (neobjavljena doktorska disertacija), Pravni fakultet Univerziteta u Bihaću, Bihać, 2015., str. 80-82.

${ }^{31}$ WHO (2001.) Promicanje jačanja mentalnog zdravlja, Informativna brošura br. 220. http://www.who.int/mediacentre/ factsheets/fs220/en/, u: Wynne, R., De Broeck, V., Vandenbroek, K., Leka, S., Jain, A., Houtman. I., McDaid, D., Park, A., Promicanje mentalnog zdravlja na radnom mjestu, Smjernice za provedbu sveobuhvatnog pristupa, Ured za publikacije Europske unije, Luxembourg, 2017., str. 8.

${ }^{32} \mathrm{O}$ faktorima koji utiču na mentalno zdravlje čovjeka, dostupno na: https://www.zzjzdnz.hr/hr/zdravlje/mentalno-zdravlje/1096, pristupljeno: 25.9.2020.

${ }^{33}$ Wynne, R., De Broeck, V., Vandenbroek, K., Leka, S., Jain, A., Houtman. I., McDaid, D., Park, A.: Promicanje mentalnog zdravlja na radnom mjestu, Smjernice za provedbu sveobuhvatnog pristupa, Ured za publikacije Europske unije, Luxembourg, 2017., str. 10.
} 
tan na svakom radnom mjestu i u svakom zanimanju. Kada se radi o kratkoročnom izvoru stresa npr. povremenom prekovremenom radu ili pojačanom periodičnom intenzitetu posla, posljedice mogu rezultirati poteškoćama u svakodnevnom funkcioniranju pojedinca (preskakanje obroka, iscrpljenost, premalo sna, glavobolje, osjećaj pritiska u prsima). Međutim, dugotrajna izloženost stresu na radnom mjestu može imati i daleko ozbiljnije posljedice u obliku razvoja mentalnih poremećaja. Najčešći mentalni poremećaji u općoj populaciji su depresija i anksiozni poremećaji. Stoga su i istraživanja o mentalnim poremećajima povezanim s radnim mjestom najčešće usmjerena upravo na ova dva poremećaja. Istraživanja su tako pokazala kako se depresija na radnom mjestu najčešće manifestira kao umor, poteškoće koncentracije te tjelesni simptomi u obliku raznih bolova. Takve osobe na poslu postaju pasivne, povučene ili neproduktivne, a depresija može utjecati i na njihovu sposobnost rasuđivanja i donošenja odluka. Istraživanja su također pokazala kako osobe s tim poremećajem češće daju otkaz ili mijenjaju svoja radna mjesta. Anksiozni poremećaji na radnom mjestu najčešće se manifestiraju kroz jako izraženu napetost, nervozu, nemir, razdražljivost i pretjeranu zabrinutost. Anksiozne osobe često traže odobravanje i podršku povezane sa svojom izvedbom. Istraživanja su pokazala da osobe koje imaju anksiozne poremećaje češće zatraže liječničku pomoć, iako ne direktno zbog anksioznosti, već najčešće kada razviju neku od psihosomatskih bolesti. ${ }^{34}$

Dugotrajna izloženost stresu na radnom mjestu, osim što negativno utječe na dobrobit radnika također ima i negativne posljedice za samu organizaciju u obliku čestih izostanaka radnika s posla (bolovanja), čestih promjena radnika, slabije produktivnosti i sl. S obzirom na sve poteškoće koje mogu prouzročiti psihosocijalni rizici radnog mjesta mnoge svjetske organizacije zajedno sa Svjetskom zdravstvenom organizacijom ukazuju na važnost primarne prevencije odnosno prepoznavanje rizičnih čimbenika i njihovo

\footnotetext{
${ }^{34} \mathrm{O}$ mentalnim poremećajima izazvanim stresom, dostupno na: https://www.zzjzdnz.hr/hr/zdravlje/mentalno-zdravlje/1096, pristupljeno: 25.9 .2020 .
}

saniranje kako bi se izbjeglo rješavanje njihovih negativnih ishoda. ${ }^{35}$

\section{Mentalno zdravlje žena radnica}

Određena istraživanja pokazuju da između društvene strukture i zdravlja i bolesti postoje brojne interakcije koje su u korelaciji s varijablom dobi, spolom, vjerom, zanimanjem, bračnim stanjem, društveno-ekonomskim statusom, etničkom i regionalnom pripadnošću, odnosima na radnom mjestu, u braku i obitelji i sl. To upućuje na zaključak da svaka kultura ima svoju specifičnu patologiju, ${ }^{36}$ pa tako i kultura koja se oslanja na tradicionalistička patrijarhalna shvaćanja o položaju i ulozi žene u društvu, u obitelji i na radnom mjestu.

„Zahtjevi koji su proizišli iz industrijske revolucije, unatoč mnogim i velikim pozitivnim promjenama, nisu u potpunosti ostvareni niti u razvijenoj zapadnoj civilizaciji, stoga nije pogrešno reći da žena i danas na području rada predstavlja socijalni problem. ${ }^{137}$ Naime, statistički podaci govore o tome kako je položaj žena na tržištu rada znatno nepovoljniji u odnosu na položaj muškaraca te da su žene u znatno većoj mjeri izložene različitim oblicima diskriminacije posebno u području zapošljavanja i rada. ${ }^{38}$ Žene se znatno više susreću s diskriminirajućim ponašanjem kako u samom postupku zapošljavanja, tako i prilikom ostvarivanja prava i sloboda iz radnog odnosa, kao npr. prilikom ostvarivanja prava na napredovanje i profesionalno usavršavanje, ostvarivanje prava na plaću, dopuste i sl., ali i uvjeta i načina

\footnotetext{
${ }^{35} \mathrm{O}$ mentalnom zdravlju na radnom mjestu, dostupno na: https:/ www.zzjzdnz.hr/hr/zdravlje/mentalno-zdravlje/1096 pristupljeno: 25.9.2020. O istoj tematici, vidi više u: Grabovac, I., Mustajbegović, J.: Healthy occupational culture for a worker-friendly workplace, Arhiv za higijenu rada i toksikologiju, 66, 2015., 1-8.

${ }^{36}$ Odnosom između društvene strukture i zdravlja i bolesti bavi se socijalna medicina. O navedenom vidu više u: Štifanić, M.: Sociološki pristupi zdravlju i bolesti, Društvena istraživanja, 7, 1998., 6(38), 833845.

${ }^{37}$ Volarević, M.: Novi feminizam i kulturalna promocija žene majke-radnice, Obnovljeni život, 67, 2012., 2, 223-237, str. 224.

${ }^{38}$ Podaci iz Eurostata prema različitim parametrima istraživanja, vidi više u: Vuković, L.: Utjecaj ulaska Republike Hrvatske u Europsku uniju na položaj žena, Diplomski rad, Sveučilište u Splitu, Ekonomski fakultet, Split, 2017.
} 
prestanka radnog odnosa. ${ }^{39}$ Ilustracije radi ovom prilikom može se istaknuti činjenica da su žene za jednake poslove plaćene znatno manje nego muškarci, da je udio žena u part time poslovima (poslovi s nepunim radnim vremenom) veći u odnosu na muškarce, a razlog za to leži upravo u činjenici da su part time poslovi manje plaćeni po satu od full time poslova (poslovi s nepunim radnim vremenom), da je zastupljenost žena u poslovima veće odgovornosti i pozicioniranosti mnogo manja, da žene danas najvećim dijelom rade u uslužnim djelatnostima i sl. ${ }^{40}$

Da bi postigle punu ravnopravnost u području rada i radnih odnosa, žene radnice prisiljene su da na radnom mjestu daju više od maksimuma svojih objektivnih mogućnosti. S obzirom na zahtjevnost i složenost postizanja takvog cilja, žene radnice sve više su usmjerene ka razvoju karijere i uopće profesionalnog života, što uključuje i obrazovanje i usavršavanje, negoli je to bilo prije, pri tome potpuno zanemarujući ili stavljajući privatni život u drugi plan. Istovremeno, spomenuti aktualni model dvije plaće, kao zadana društvena norma, nameće ženi potrebu znatno većeg angažmana u profesionalnom životu. S druge strane, one žene radnice koje nastoje jednaku važnost pridati i privatnom i profesionalnom životu nailaze na brojne prepreke, počevši od nerazumijevanja i nedostatka podrške pa čak i osude unutar obitelji i bližeg životnog okruženja, pri čemu niti šira društvena zajednica, uključujući i zakonodavce nisu naklonjeni postizanju naznačenog cilja, budući da ne predviđaju mogućnost fleksibilnih radni aranžmana poput kombiniranja rodiljnog dopusta i skraćenog radnog vremena. ${ }^{41}$

Pitanje usklađivanja privatnog i profesionalnog života pred žene radnice stavlja brojne pritiske, odluke i dileme, kako na privatnom, tako i na profesionalnom planu, što stvara kontinuirani

${ }^{39}$ Godišnji izvještaji o rezultatima aktivnosti Institucijeombudsmena za ljudska prava u Bosni i Hercegovini, dostupno na: https://www. ombudsmen.gov.ba/Dokumenti.aspx? id=27\&tip=1\&lang=BS, pristupljeno 13.12.2020.

${ }^{40}$ Podaci dostupni u: Galić, B.: Žene i rad u suvremenom društvu - značaj "orodnjenog" rada. Sociologija i prostor, 49, 2011., 1, 25-48, str. 27-32.

${ }^{41} \mathrm{O}$ poslovnom modelu fleksibilnog zapošljavanja-MamForce, razlozima i potrebi implementacije, dostupno na: http://zenskaposla.com/poslovni-model-fleksibilnog-zaposljavanja-mamforce/442/, pristupljeno: 13.12 .2020 . stres koji neminovno utječe i na njezino mentalno zdravlje te izaziva određene poremećaje poput depresije, anksioznosti i drugih sličnih mentalnih poremećaja. ${ }^{42}$ Kada se govori o izvorima i čimbenicima rizika koji na to utječu, može se govoriti o izvorima osobnog i društvenog karaktera gdje posebno mjesto zauzimaju čimbenici rizika koji su $u$ vezi sa željenim ili neželjenim životnim događajima poput rođenja djeteta. S tim u vezi, čimbenik nedostataka društvene podrške koja bi ženi radnici olakšala proces prilagođavanja novonastalim okolnostima i kasnije vraćanje u uobičajene životne tokove zauzima posebno mjesto u hijerarhiji čimbenika rizika. Nadalje, izvor rizika može biti i samo radno mjesto putem čimbenika rizika kao što su: priroda posla, obim, raspored i tempo rada, radno okruženje, organizacijska kultura i funkcija, međuljudski odnosi na radu, uloga u organizaciji, razvoj karijere i drugi slični čimbenici. Nisu zanemarivi niti izvori rizika društveno-ekonomske prirode gdje se posebna pozornost posvećuje čimbenicima rizika kao što je strah od nezaposlenosti i stanje nezaposlenosti, vrsta ugovora o radu, sigurnost posla i prihodi, kao i radno i socijalno zakonodavstvo i sigurnost i zdravlje na radu. ${ }^{43}$

Kada se govori o mogućem smanjivanju jaza između obiteljskog i profesionalnog života žene, veoma značajnu ulogu ima spomenuti radnopravni institut rodiljnog dopusta. S obzirom na prirodu instituta rodiljnog dopusta te njegovu normativnu regulaciju, ono upravo omogućuje ženi majci ostvarivanje balansa između obiteljskih i poslovnih obveza. Ipak, pri regulaciji i primjeni ovog instituta treba imati posebnu mjeru, jer posebno odredbe o zaštiti žene i materinstva, iako ih prividno štite od diskriminacije, ponekad mogu prouzročiti diskriminaciju trudnih žena. S obzirom na tradicionalno patrijarhalno shvaćanje o ulozi žene u društvu, kao i neadekvatnu populacijsku i natalitetnu politiku, radno i socijalno zakonodavstvo u Bosni i Hercegovini sadrži odred-

\footnotetext{
${ }^{42} \mathrm{O}$ uticaju stresa $\mathrm{u}$ vezi s radnim mjestom, dostupno na: https:// www.zzjzdnz.hr/hr/zdravlje/mentalno-zdravlje/1096, pristupljeno: 13.12.2020.

${ }^{43} \mathrm{O}$ važnosti i rizicima po mentalno zdravlje na radnom mjestu, vidi više: Wynne, R., De Broeck, V., Vandenbroek, K., Leka, S., Jain, A., Houtman. I., McDaid, D., Park, A.: Promicanje mentalnog zdravlja na radnom mjestu, Smjernice za provedbu sveobuhvatnog pristupa, Ured za publikacije Europske unije, Luxembourg, 2017., str. 8-18.
} 
be koje ne idu u prilog zaposlenoj ženi, počevši od duljine trajanja rodiljnog dopusta, visine naknade plaće za vrijeme rodiljnog dopusta, pravo na korištenje godišnjeg odmora nakon rodiljnog dopusta, (ne)postojanja i visine dječjeg dodatka i druge odredbe.

Ipak, jedan problem se posebno ističe, a to je pitanje prava na korištenje godišnjeg odmora nakon rodiljnog dopusta. U kontekstu zaštite prava žena radnica i njihovog mentalnog zdravlja, ovo pravo predstavlja veoma značajan institut radnog prava. Prije svega, nesporna je činjenica da se za ženu majku i radnicu radi o iznimno važnom i emocionalno osjetljivom trenutku kada se iz okruženja i topline doma i majčinstva vraća u radno okruženje, pri čemu brigu o djetetu prepušta drugim osobama. Sam po sebi taj trenutak je posebno emocionalan, a istovremeno i vrlo stresan. S druge strane, ako majka nema adekvatnu podršku (institucionalno, u obitelji i radnom okruženju), njezino mentalno zdravlje može biti narušeno u manjem ili većem intenzitetu. Prema važećem radnom zakonodavstvu u Bosni i Hercegovini, ${ }^{44}$ žena radnica koja odluči koristiti rodiljni dopust u maksimalnom trajanju, prešutno se odriče prava na godišnji odmor, a ako odluči da koristi godišnji odmor, istovremeno se odriče prava na korištenje rodiljnog dopusta u maksimalnom trajanju, odnosno odriče se dijela rodiljnog dopusta. Dakle, ove dvije vrste odsutnosti s rada isključuju jedna drugu iako se radi o zajamčenim pravima i u jednom i u drugom slučaju, pri čemu je pravo na godišnji odmor zakonom izričito zaštićeno na način da se radnik ne može odreći toga prava, niti se radniku pra-

${ }^{44}$ Misli se na zakon o radu Federacije Bosne i Hercegovine, Zakon o radu Republike Srpske i Zakon o radu Brčko Distrikta Bosne i Hercegovine, jer se o pitanju ovog instituta radnog prava ne razlikuju. vo na godišnji odmor može uskratiti, niti mu se može izvršiti isplata naknade umjesto korištenja godišnjeg odmora. ${ }^{45}$ Zakonodavac je ipak trebao pokazati više senzibiliteta prema ženama radnicama te predvidjeti mogućnosti prenošenja cije$\log$, a ne samo dijela godišnjeg odmora u narednu godinu, kada su u pitanju žene radnice koje koriste rodiljni dopust u maksimalnom trajanju. Takva mogućnost mogla bi se smatrati „pozitivnom mjerom" u zaštiti žena radnica uopće, te mjerom pronatalitetne, demografske i socijalne politike, koja zasigurno ne bi ekonomski štetila poslodavcima i javnim budžetima. Istovre-

\footnotetext{
${ }^{45} \mathrm{Za}$ pitanje ostvarivanje prava na godišnji odmor žena radnica koje su koristile rodiljni dopust u maksimalnom trajanju značajne su odredbe zakona koje govore o mogućnosti korištenja godišnjeg odmora u dijelovima. Naime, ako radnik koristi godišnji odmor u dijelovima, u obvezi je da prvi dio godišnjeg odmora u minimalnom trajanju od 12 radnih dana iskoristi tijekom kalendarske godine za koju ostvaruje to pravo, a preostali dio u narednoj kalendarskoj godini najkasnije do ostvarivanja prava na novi godišnji odmor, tj. najkasnije do 30. lipnja naredne godine. Pri tome je zakonom decidirano propisano da radnik koji ne iskoristi dio godišnjeg odmora u kalendarskoj godini, nema pravo prenošenja godišnjeg odmora u narednu godinu. Iz navedenog slijedi da radnik koji nije iskoristio dio godišnjeg odmora u kalendarskoj godini, gubi pravo na korištenje godišnjeg odmora u potpunosti. Jedini izuzetak od ovog pravila predviđen je u slučaju prestanka ugovora o radu, kada je poslodavac dužan radniku koji nije iskoristio cijeli ili dio godišnjeg odmora isplatiti naknadu umjesto korištenja godišnjeg odmora u iznosu koji bi primio da je koristio cijeli, odnosno preostali dio godišnjeg odmora, ako godišnji odmor ili njegov dio nije iskoristio krivicom poslodavca.

Ako se autori referiraju na odredbe zakona kojima se uređuje pitanje rodiljnog dopusta te ih analiziraju u kontekstu odredaba o pravu na godišnji odmor, za zaključiti je da žena radnica koja koristi rodiljni dopust u maksimalnom trajanju nema pravo na godišnji odmor. Za potrebe analiziranja ovog problema uputno je postaviti i razmotriti hipotetički slučaj. Naime, ako je žena radnica bila odsutna s rada, npr. od 8.1.2016. godine do 6.1.2017. godine radi korištenja rodiljnog dopusta, ona ne može koristiti pravo na godišnji odmor za 2016. godinu, s obzirom da nije započela korištenje godišnjeg odmora u kalendarskoj 2016. godini te je time, ne samo izgubila pravo na prenošenje dijela godišnjeg odmora u narednu godinu, već i pravo na godišnji odmor u potpunosti. $U$ hipotetičkom slučaju, majka rodilja morala bi prekinuti korištenje rodiljnog dopusta znatno prije kraja kalendarske godine da bi mogla započeti korištenje godišnjeg odmora u trajanju od najmanje 12 radnih dana u prvom dijelu, kako zakonodavac nalaže. Važno je još jednom napomenuti da se rodiljni dopust mora koristiti u kontinuitetu i da se jednom prekinuto ne može kasnije nastaviti.
} 
meno, zaštita žena radnica iz razloga trudnoće i materinstva, kao i zaštita mentalnog zdravlja žena radnica opravdava drugačiji tretman žena. ${ }^{46}$ Protivnici ovakvog zakonodavnog rješenja smatraju da se, osim negativnih posljedica ekonomsko-financijske prirode za poslodavce prije svega, privilegiranjem žena u pogledu korištenja godišnjeg odmora nakon rodiljnog dopusta gubi smisao i svrha samog godišnjeg odmora, a to je odmor od rada, psihofizička rehabilitacija radnika, planiranje različitih aktivnosti u privatnom životu itd. Oni drže da je žena tijekom rodiljnog dopusta svakako odsutna s rada, da provodi vrijeme kod kuće u krugu obitelji, da odmara i rehabilitira se te da bi korištenje godišnjeg odmora nakon toga potpuno izgubilo svoj smisao i bilo nepotrebno. Međutim, svaka žena majka, kao i oni koji su boravili u okruženju majke nakon porođaja i u prvim mjesecima, pa i godinama djetetovog života, zna koliko je zahtjevna zadaća konstantne brige i njege djeteta te se nipošto ne može smatrati da je majka porodilja tijekom rodiljnog dopusta zapravo bila na svojevrsnom odmoru. Osim toga, kako je već spomenuto, za majku rodilju i sam povratak u radno okruženje može biti vrlo stresan, često i dramatičan te se u tom trenutku ona nalazi pred posebnim izazovom usklađivanja privatnog i profesionalnog života. ${ }^{47}$

\section{ZAKLJUČAK}

Za usklađivanje privatnog i profesionalnog života žena radnica i u vezi s time očuvanja njiho-

\footnotetext{
${ }^{46}$ Pronatalitetna zakonodavna rješenja ovog i sličnih problema nisu novost u uporednim zakonodavstvima. Tako je npr., srbijanski zakonodavac predvidio izuzetak od pravila da se samo dio godišnjeg odmora može prenijeti u narednu godinu. Naime, prema Zakonu o radu Srbije godišnji odmor se, po pravilu, koristi u kalendarskoj godini za koju se ostvaruje pravo na godišnji odmor. Nadalje je propisao da se godišnji odmor može koristiti u dva dijela. Ako radnik koristi godišnji odmor u dijelovima, prvi dio se koristi u trajanju od najmanje dva radna tjedna tijekom kalendarske godine, a drugi dio najkasnije do 30. lipnja naredne godine. Pri tome je iznimno predviđeno da radnik koji nije u cjelini ili djelomično iskoristio godišnji odmor u kalendarskoj godini zbog odsutnosti s rada zbog korištenja rodiljnog dopusta, odsutnost s rada zbog njege djeteta i posebne njege djeteta, ima pravo da taj odmor iskoristi do 30. lipnja naredne godine. Prema tome, žena radnica koja zbog rodiljnog dopusta i odsutnosti s rada zbog njege djeteta nije iskoristila, niti započela korištenje godišnjeg odmora u kalendarskoj godini za koju ostvaruje pravo na godišnji odmor, ima pravo da taj odmor iskoristi do 30. lipnja naredne godine (član 73., Zakon o radu Republike Srbije, Službeni glasnik Republike Srbije, broj 24/05., 61/05., 54/09., 32/13., 75/14. i 13/17.).

${ }^{47} \mathrm{O}$ pravu žena radnica na korištenje godišnjeg odmora poslije rodiljnog dopusta, vidi više u: Bešlagić, J.: Pravo žena radnica na godišnji odmor poslije porođajnog odsustva u Federaciji Bosne i Hercegovine, Pravna misao, 9-10, 2018., 22-39.
}

vog mentalnog zdravlja, veoma je važno nekoliko čimbenika. Prije svega, zbog tradicionalnih, patrijarhalnih i stereotipnih shvaćanja o ulozi žene u obitelji i društvenoj zajednici, smatra se da je ženi imanentnija uloga majke i kućanice negoli radnice i društvu korisne individue. Takav stav je veoma često prisutan i u obitelji pa za razvoj profesionalnog života žene radnice, a istovremeno i za ostvarivanje uloge majke i kućanice, žena nerijetko nema razumijevanje niti podršku čak i članova najuže obitelji. Osim toga, i sami poslodavci nemaju senzibiliteta za zahtjevnu dvostruku ulogu žene, u kućanstvu i u profesionalnom životu, već su usmjerene na vlastiti interes, ostvarivanje dobiti ili druge oblike pozitivnog poslovanja radne organizacije. Također, niti zakonodavstvo nije u potpunosti naklonjeno ženi radnici i ne prati suvremene emancipacijske društvene procese niti potrebe žena u njihovim dvostrukim društvenim ulogama na privatnom i profesionalnom planu.

Stoga je, zbog lakšeg uspostavljanja ravnoteže između privatnog i profesionalnog života žena radnica, a time i radi očuvanja njihovog mentalnog zdravlja često narušenog zbog konstantnih pokušaja ostvarivanja takvog cilja i očekivanja, neophodno činiti značajne pomake u pogledu osvještavanja uže i šire društvene zajednice o ovom problemu. Pri tome je važno od najranijeg uzrasta unutar edukativnih procesa govoriti o ovom problemu, ali i na druge načine senzibilizirati javnost o ovom pitanju, ukazujući na potrebnu podršku koju žena majka radnica treba da bi ostvarila ovu vrlo zahtjevnu dvostruku ulogu. Pored toga i radne organizacije moraju biti svjesne da rad utječe na različite aspekte života čovjeka, pa je stoga iznimno važno da kreiraju politike i programe koji omogućuju radnicima uspostaviti dobru ravnotežu između posla i privatnog života. ${ }^{48}$ Ono što je za ženu radnicu od posebnog značaja unutar radne organizacije jest razvijanje adekvatnih strategija povratka na rad kada je u pitanju povratak nakon rodiljnog dopusta. Naime, postoje brojni razlozi zašto bi poslodavci trebali aktivno upravljati povratkom na rad ljudi onda kada postoji određeni rizik za njihovo mentalno zdravlje. Poslodavci imaju osnovnu ob-

\footnotetext{
${ }^{48}$ Grabovac, I., Mustajbegović, J.: Healthy occupational culture for a worker-friendly workplace, Arhiv za higijenu rada i toksikologiju, 66, 2015., 1-8, str. 5 .
} 
vezu osigurati da ne krše zakonodavstvo u pogledu jednakosti ili zabrane diskriminacije, odnosno da ne diskriminiraju radnika koji se vraća nakon odsutnosti na osnovi medicinskih razloga, pod koje se svakako može podvesti i odsutnost s rada zbog porođaja. Od uspostavljanja odgovarajućih strategija povratka na rad koristi imaju i radnici i poslodavci: vodi se računa o zdravlju i osobnoj dobrobiti radnika, a poslodavcima se smanjuju troškovi zbog odsutnosti s rada. Na kraju, veoma je važna i zakonska regulativa koja bi bila naklonjena obiteljskom životu i položaju žene unutar radnog odnosa u vezi s tim te adekvatno regulirala pitanje mogućnosti privremenog prekida rada, rad s nepunim i fleksibilnim radnim vremenom, rodiljni dopust za oba roditelja, pravo na korištenje godišnjeg odmora nakon rodiljnog dopusta itd. Pri tome je od posebnog značaja i uloga institucija koje se bave organiziranom brigom za djecu i starije osobe, a koja je prilagođena individualnim potrebama konkretne obitelji i što lakšem usklađivanju njihovih radnih i obiteljskih obveza.

\section{LITERATURA}

Bašić, A.: Rodne uloge i stereotipi, Helsinški parlament građana, Banja Luka, 2007.

Bešlagić, J.: Pravo žena radnica na godišnji odmor poslije rodiljnog dopusta u Federaciji Bosne i Hercegovine, Pravna misao, 9-10, 2018., 22-39.

Bešlagić, J.: Zabrana diskriminacije pri zapošljavanju i na radu - evropski i nacionalni aspekt (neobjavljena doktorska disertacija), Pravni fakultet Univerziteta u Bihaću, Bihać, 2015.

Borić, R.: Šinko, M., Prlenda, S.: Ostvarivanje politike jednakih mogućnosti za tekstilne radnice/ ke, Centar za ženske studije, Zagreb, 2009., 3637.

Direktiva Vijeća 2010/18/EU od 8. ožujka 2010. godine o provedbi revidiranog Okvirnog sporazuma o roditeljskom dopustu, 32010L0018, OJ, L 68.

Dobrotić, I.: Politike usklađivanja obiteljskih obaveza i plaćenog rada i položaj roditelja na tržištu rada, Revija za socijalnu politiku, 22, 2015. 3, 353-374.
Galić, B.: Žene i rad u suvremenom društvu značaj "orodnjenog" rada. Sociologija i prostor, 49, 2011., 1, 25-48, 29.

Galić, V.: Zaštita majčinstva u Europskoj uniji i hrvatski zakonodavni okvir, Pravni vjesnik: C̆asopis za pravne i društvene znanosti Pravnog fakulteta Sveučilišta J.J. Strossmayera u Osijeku, 30, 2014., 2, 435-447.

Godišnji izvještaji o rezultatima aktivnosti Institucije ombudsmena za ljudska prava u Bosni i Hercegovini, dostupno na: https://www.ombudsmen. gov.ba/Dokumenti.aspx?id=27\&tip=1 \&lang=BS, pristupljeno 13.12.2020.

Grabovac, I., Mustajbegović, J.: Healthy occupational culture for a worker-friendly workplace, Arhiv za higijenu rada i toksikologiju, 66, 2015., 1, 1-8.

Izvještaj Europske komisije o napretku za Republiku Hrvatsku iz 2005. godine, dostupno na: https://ec.europa.eu/neighbourhoodenlargement/sites/near/files/archives/pdf/key_documents/2005/package/sec_1424_final_progress_ report_hr_en.pdf, pristupljeno: 5.9.2019.

Jergovski, A.: Stakleni strop, Granice u napredovanju žena na radnom mjestu, Obnovljeni život, 65, 2010., 3, 403-412.

Mahlburg $v$ Land Mecklenburg-Vorpommern, ESP, C-207/98.

O faktorima koji utiču na mentalno zdravlje čovjeka, dostupno na: https://www.zzjzdnz.hr/ hr/zdravlje/mentalno-zdravlje/1096, pristupljeno: 25.9.2020.

O mentalnim poremećajima izazvanim stresom, dostupno na: https://www.zzjzdnz.hr/hr/ zdravlje/mentalno-zdravlje/1096, pristupljeno: 25.9.2020.

O poslovnom modelu fleksibilnog zapošljavanja-MamForce, razlozima i potrebi implementacije, dostupno na: http://zenska-posla.com/ poslovni-model-fleksibilnog-zaposljavanja-mamforce/442/, pristupljeno: 13.12.2020.

O uticaju stresa u vezi s radnim mjestom, dostupno na: https://www.zzjzdnz.hr/hr/zdravlje/mentalno-zdravlje/1096, pristupljeno: 13.12.2020. 
Rebac, I.: Izravni i neizravni oblici diskriminacije na tržištu rada, zaštita od diskriminacije u kolektivnim ugovorima u Republici Hrvatskoj, Radno pravo, 7-8, 2006., 1, 6-28.

Stec i drugi v UK, ESLJP, 65731/01 i 65900/01.

Susanne Lewen $v$ Lothar Denda, ESP, C-333/97.

Štifanić, M.: Sociološki pristupi zdravlju i bolesti, Društvena istraživanja, 7, 1998., 6(38), 833845.

Učur M., Laleta, S.: Konvencije Međunarodne organizacije rada sa komentarima, TIM press, Pravni fakultet Sveučilišta u Rijeci, Zagreb, 2007.

Vinković, M:, Zaštita majčinstva - stanje i perspektive hrvatskog radnog zakonodavstva, Radno pravo, 3, 2006., 1, 6-12.

Volarević, M.: Novi feminizam i kulturalna promocija žene majke-radnice“, Obnovljeni život, 67, 2012., 2, 223-237.

Vuković, L.: Utjecaj ulaska Republike Hrvatske u Europsku uniju na položaj žena, Diplomski rad, Sveučilište u Splitu, Ekonomski fakultet, Split, 2017.

Wynne, R., De Broeck, V., Vandenbroek, K., Leka, S., Jain, A., Houtman. I., McDaid, D., Park,
A.: Promicanje mentalnog zdravlja na radnom mjestu, Smjernice za provedbu sveobuhvatnog pristupa, Ured za publikacije Europske unije, Luxembourg, 2017.

Zakon o penzijskom i invalidskom osiguranju Federacije Bosne i Hercegovine, Službene novine Federacije Bosne i Hercegovine, broj 13/18.

Zakon o penzijskom i invalidskom osiguranju Republike Srpske, Službeni glasnik Republike Srpske, broj 134/11., 82/13., 96/13. - odluka US i 103/15.

Zakon o radu Brčko Distrikta Bosne i Hercegovine, Službeni glasnik Brčko Distrikta Bosne i Hercegovine, broj 34/19.

Zakon o radu Federacije Bosne i Hercegovine, Službene novine Federacije Bosne i Hercegovine, broj 26/16. i 89/18.

Zakon o radu Republike Srbije, Službeni glasnik Republike Srbije, broj 24/05., 61/05., 54/09., 32/13., 75/14. i 13/17.

Zakon o radu Republike Srpske, Službeni glasnik Republike Srpske, broj 1/16. i 66/18.

Zakon o ravnopravnosti spolova Bosne i Hercegovine, Službeni glasnik Bosne i Hercegovine, broj 32/10., pročišćeni tekst. 


\section{PRIVATE AND PROFESSIONAL LIFE OF FEMALE EMPLOYEES AND THEIR EFECTS ON MENTAL HEALTH AND THE RIGHT TO MATERNITY LEAVE}

SUMMARY: Bringing into harmony the private life, above all motherhood, care of children, home, and numerous other obligations, and professional life which includes education, employment, further training and dedication to work, pose extremely complex demands on employed women. Women today are doubly or triply burdened. Often they are faced with a choice between private and professional life and challenges that are not typical for men. Some of the consequences are that women take a minimum maternity leave and then have to delegate the care for children, family and home to other persons or to institutions just to keep their job, have time for professional development and achieve promotion at work. The constant pressures both in their private and professional life may lead to certain disorders and conditions that can affect their mental health. The current legislature in Bosnia and Herzegovina offer minimum of rights, quite insufficient for attaining a satisfactory balance between private and professional life of employed women.

Key words: private life, professional life, women workers, mental health, maternity leave, legislature in Bosnia and Herzegovina 